\title{
Research on the Mechanism of Promoting Public Participation in the People's Livelihood Reform Policy Process
}

\author{
Bing Li \\ School of Public Administration \\ University of Electronic Science and Technology of China \\ Chengdu, China
}

\author{
Juan Du \\ School of Public Administration \\ University of Electronic Science and Technology of China \\ Chengdu, China
}

\begin{abstract}
With the improvement of democratization degree of the society and the increase of citizens' awareness of democracy, more and more people want to participate in the process of policy implementation and influence the formulation and implementation of policies by expressing their own interest claims. However, in China, there are still some deficiencies in the public participation in the people's livelihood policies. For example, the source of policy issues is narrow and the consideration of the needs of the masses is relatively little; the formulation of policies is dominated by the government, and the public participation is in some degree only a form; the policy evaluation is mainly conducted by the government itself; etc.. In order to promote public participation in the policy process and improve the operation efficiency of policies, this paper will conduct research on the mechanism which promotes policy issues' coming from the people, policies' being formulated according to people's ideas, and policies' being evaluated by the people, and promote public participation in the operation of the people's livelihood policies.
\end{abstract}

Keywords—public participation; people's livelihood reform; policy operation

\section{INTRODUCTION}

Public participation refers to that the public directly or indirectly expresses their interests, wishes, and opinions about the formulation and implementation of public policies within legal limits and through certain procedures and methods, thus affecting the formulation and implementation of policies ${ }^{1}$. It is the most direct and most important way to combine the public nature of public administration and civil democratic power, ensure the fairness of public resource allocation and ensure the scientificity of public policies. However, the "participation" in public participation is not the purpose. Public participation is the process by which the public interacts and negotiates with government agencies to influence public decision-making and eventually reach a "consensus" with government agencies ${ }^{2}$. Public participation does not refer to the participation in a certain stage of the policy process, it refers to the participation in entire process of the policy, including the establishment of policy issues, policy formulation and policy assessment ${ }^{3}$. Public participation is a way for the public to realize their value appeal, the basic requirement for the democratization and scientificization of public decision-making and an effective means to improve the legalization degree of policies ${ }^{4}$.

In general, the public will selectively participate in certain policy processes, and people are more inclined to participate in policy issues that are directly related to their own interests. In other words, the closer the relationship between the policy and the public's interests is, the higher the degree of public participation in the policy is ${ }^{5}$. The issue of people's livelihood is a key and difficult issue in the administrative decisionmaking of the government. It is closely related to the interests of the public. Major decisions on people's livelihoods must involve the public participation. Of course, in addition to the interest-related issue, the government's political support, leaders' capabilities, and policy decision-making procedures will also affect public participation.

There has been some research on public participation in the policy process, but it is not yet in depth: On the one hand, the research is mainly about the public participation in a certain stage of the policy process, most of the researches are about public participation in the process of policy formulation. There are fewer studies on the processes of the establishment of policy issues and the evaluation of the policy. On the other hand, in the past, scholars mainly studied the two main bodies, the government and the public, and did not conduct in-depth research on the organizational mechanisms connecting the government and the public. Therefore, this paper will study the entire operation process of people's livelihood policies, analyze the three stages including the establishment of policy issues, policy formulation and policy evaluation, and conduct in-depth discussion of mechanisms which promote public participation.

\section{PROBLEMS IN THE CURRENT OPERATION PROCESS OF THE PEOPLE'S LIVELIHOOD POLICY}

\section{A. The Source of Policy Issues Is Narrow and There Is Insufficient Consideration of Public Needs}

From the perspective of policy establishment logic, policy issues originate from people's unsatisfied personal needs, but not all unmet needs are policy issues. Policymakers must perceive, define, and integrate the problems and ultimately determine policy issues. 
At present, the people's livelihood policy presents a characteristic of internal input, that is, policy issues are mainly derived from the political system, rather than from the direct needs of the public. When it comes to perceiving policy issues, policy makers often ignore the fact that policy issues originate from different needs of the public. They tend to observe with great subtlety by themselves and summarize, making policy issues mostly stem from the personal preferences of elites, the government's theoretical assessment of various socioeconomic indicators and statistical data, and the feedback of policy executives. Decision makers do not systematically analyze the needs of the public, so that policy issues do not really come from the people. The policy issues do not come from the reality so that they may have unilateral features and even be primary and secondary fuzzy, and they cannot reflect the current focus of people's livelihood.

\section{B. The Formulation of Policies Is Led by the Government and the Public Participation Is Formalized}

The public nature of the people's livelihood policy requires that the policy must represent the interests of the public. Therefore, the public must participate in the formulation and implementation of policies. However, in the traditional policymaking model of China, the administrative agencies are regarded as representatives of the public interest. ${ }^{7}$ Officials naturally become advocates of public interests and have the power to formulate, select, and finalize the policy plan. With the increasing demand for political democratization and the increasing awareness of public participation, people's voice for "combination of public participation, expert argumentation, and government decision-making" has become increasingly louder. Experts have frequently appeared in the formulation processes of various policies. They are involved in policy formulation in the form of being consulted, but a lot of expert participation is just an excuse of the government to increase the rationality of the policy ${ }^{8}$. Policy formulation is still dominated by the government.

Public participation faces a dilemma of being formalized. At present, the methods of public participation adopted by the government include publicity, publicly listening to opinions, opinion polls, hearings, etc. The methods are simple, the forms are limited, and some of methods are formalized. For example, the urban planning draft must be publicized. The most common method used by the government is to place an announcement in the planning hall for display. The public cannot see it and may not understand it ${ }^{9}$. The hearings are often considered to be only a form, such as the bad reputation of price hearings that "there must be a rise in every hearing".

\section{The Subject of Policy Evaluation Is Single, the Assessment Criteria Is Subjective}

At present, the vast majority of assessments for people's livelihood policies are departmental self-assessments. There is little social organization and public participation. That is, policy makers or executives conduct self-summaries, and write summary reports to evaluate the effectiveness of policy implementation. The assessment subjects are relatively single and there are few third-party assessment agencies involved. The public is not truly involved in the assessment process.
The public is the main recipient and beneficiary of the people's livelihood policies. Therefore, whether the public has benefited from it is the best criterion for evaluating whether the people's livelihood policy is effective. On the one hand, there is almost no public participation in the self-assessments of departments, and the evaluators do not use the public's sense of acquisition as an evaluation index of the policy's effect. On the other hand, the self-assessment is less professional than the third-party assessment. Most of the evaluators do not possess the professional knowledge of the evaluation. They prefer to use subjective judgments rather than objective fact analyses in the policy evaluation. The evaluation criteria are subjective.

\section{RESEARCH ON THE MECHANISM OF PROMOTING POLICY ISSUES' STEMMING FROM THE PEOPLE}

The people's livelihood policy must focus on addressing the most urgent needs of the public, but not every demand can be risen to a policy issue. The needs of the public are diverse. It is difficult for the government to fully understand the needs of the public only by itself. Therefore, the public is required to participate and actively express their own needs. To this end, this article believes that it is necessary to establish a metaproblem construction mechanism, a public agenda normalization mechanism, and a democratic consultation mechanism to promote the public's expression of their needs, enable the government to receive diverse public needs, communicate and negotiate with the public, and extract policy issues that need to be solved urgently.

\section{A. Meta-problem Construction Mechanism}

Among the diverse needs of the masses, there are individual needs and common needs. For the individual needs, government departments can only conduct individual processing. However, for the common needs, government departments must pay attention to them. They may be problems that need to be solved urgently at present, and may even be raised to the policy level. So, how can we find common needs in the public demands? Decision-makers must systematically analyze, summarize, and generalize the diverse needs of the public, find the nature of the problems, and get the root causes why public needs are not met, which are the metaproblems ${ }^{11}$. After finding out the meta-problems, the government can deal with the policy issues from the source and establish reasonable target orientations by formulating targeted measures to prevent deviations in policy values.

\section{B. Public Agenda Normalization Mechanism}

Giving full play to the role of the public is not only the internal requirement of our country's democratic political construction, but also the core idea of social governance theory. Some policies do not necessarily require public participation, such as national defense foreign policy, but the people's livelihood policy is closely related to people's lives, under the background of collaborative governance, the public agenda is an inevitable choice. There should be detailed provisions on how to set the public agenda and what effects to achieve. This will provide policy makers with clear reference and ensure public participation with institutional guarantees. In order to achieve wide public participation, policy makers must 
establish a convenient and effective platform for the public to participate. For example, we can set up demand receiving stations taking a street or a community as a unit. NPC and government personnel will accept the appeals of people together. At the same time, Party members can go deep into the community to conduct public opinion surveys and collect opinions from the masses. Promote public participation in all aspects of people's lives, make people develop a democratic way of life, enable the public to have rational and equal consultations and dialogues with government authorities, and promote socialist democratic political construction.

\section{Democratic Consultation Mechanism}

Democratic negotiation is a kind of dialogue between the government and the public with specific goals. It mainly solves problems or eliminates conflicts through the dialogue mechanism. Ideally, democratic consultation should exist in the entire process of setting the policy agenda. After the social issues enter the government agenda from the public agenda, they will inevitably be analyzed and selected. It is particularly important for the government and citizens to express their own views and conduct rational consultation and dialogue. The democratic consultation mechanism not only refers to the democratic publicity of policy decisions made by the people's congresses, political consultative conferences, party committees, and governments, but also includes the consultative democracy autonomy of grass-roots groups and social organizations. The operation of the democratic consultation mechanism needs the rational participation of the masses. The public should increase their knowledge of public policy so as to improve their level of participation. At the same time, the government should try to increase the enthusiasm, initiative, and creativity of the public in participating in decision-making, so that the public can rationally make recommendations, and the government management and social autonomy can be effectively linked.

\section{RESEARCH ON THE MECHANISM OF PROMOTING THE Formulation OF POLICY PlANS REFERRING TO PEOPLE'S OPINIONS}

We emphasize that people's livelihood policies should be formulated "referring to people's opinions". The "people" here refers not only to ordinary people but also to experts and scholars with relevant professional knowledge. Asking the people for opinions on the formulation of policy plans is to realize the diversification of design subjects under the leadership of the government. This requires the establishment of a government information disclosure system so that each subject can have sufficient information. The public's supervision and feedback on the policy design process should be strengthened and the accountability system should be established to avoid the problem of unclear responsibilities caused by the diversity of subjects.

\section{A. Government Information Disclosure System}

Generally, the government holds all the relevant information about policies and the information that nongovernment entities can obtain is limited. For non-government entities, they must obtain the necessary information in order to participate in the design of the policy plans. Only with a comprehensive understanding of the issues, can the nongovernment entity analyze problems in depth, identify the crux of problems and design policy plans that can solve problems. Therefore, the government must fully disclose the information. However, information cannot be freely disclosed. The government must disclose information within legal limits. The forms and methods of disclosure must comply with the laws. The government's disclosure of information ensures the public's right to know the information and is a prerequisite for the effective participation of citizens. Only if the public has a comprehensive understanding of the relevant policy information can they provide constructive opinions and suggestions.

\section{B. Public Supervision and Feedback Mechanism}

Although government officials are representatives of the public interest, they are also representatives of departmental interests and it is inevitable that they do some self-interested behavior. Therefore, it is necessary to supervise and feedback on the design process of the policy plan. The supervision and feedback mentioned here are mainly performed by the public. On the one hand, policy makers should listen carefully to public opinions during the design process, receive public opinions through the Internet, telephone, mailboxes, policy hearings, etc., absorb the wisdom of the public and constantly improve the policy plan. On the other hand, policy-makers should also actively collect opinions of the masses, contact the key persons through public opinion surveys, and actively understand their ideas in order to ensure that the policies are in line with public opinions. The establishment of public supervision and feedback mechanism has made the policy design process public. The policy design process can accept public supervision and information feedback anytime and anywhere, which can make the policy plan more scientific.

\section{Accountability Mechanism}

Establish an accountability mechanism for the entities of public policy plan design, link the follow-up implementation of the policy plan with the design entities, require the designers to strictly follow the objectives, principles, and related regulations of the policy establishment, strictly assess the legality, rationality and feasibility of the plan in the process of formulating the plan, make the designer who does not follow the regulations and has made wrong decisions responsible for his behavior. Through the methods mentioned above, the termination of programs can be reduced and there will be less waste of manpower and material resources. 13 At the same time, there is usually an expert argumentation link in the design process of policy options. However, there is no reasonable constraint mechanism to ensure the role of experts in the system. Most of the expert argumentation links are formalized, causing that the scientific nature and professionalism of the policy cannot be guaranteed. Therefore, it is very necessary to make experts responsible for their behavior. This can strengthen the sense of responsibility of experts and improve the effectiveness of expert argumentation. 


\section{RESEARCH ON THE MECHANISM OF PROMOTING THE Evaluation of Policies By PEOPLE}

The public is the direct recipient of the people's livelihood policy. The public's sense of acquisition is the best indicator for evaluating the effectiveness of the people's livelihood policy. However, the main body of the people's livelihood policy assessment is the government. It is necessary to build a multi-participation mechanism to let the public participate in the process of policy evaluation. It is necessary to construct the system safeguard mechanism so that public participation can be guaranteed by certain regulations rather than happen randomly.

\section{A. Multi-party Participation Mechanism}

Build a multi-participation mechanism for the assessment of people's livelihood policies, make professional assessment agencies, social organizations, and the public participate in assessments, and absorb the wisdom of people to formulate policy assessment criteria and select policy assessment methods. On the one hand, improve the existing selfassessment approach. Improve the self-examination mechanism of governments and their departments, formulate rigorous assessment criteria, and take the public's sense of acquisition as one of the criteria in the evaluation system. The main subject of the policy assessment should survey public's sense of acquisition through questionnaires, interviews, etc., collect policy recipients' evaluation on the effectiveness of policy operations, evaluate the realization degree of policy goals based on public's sense of acquisition, and improve policies based on public suggestions. On the other hand, expand the role of third-party assessments. Compared with government agencies, third-party organizations are more specialized and have more assessment methods. Therefore, we must establish a social consultation and evaluation mechanism and, under the combined effect of self-evaluation and thirdparty assessment, conduct a comprehensive assessment for the effectiveness of policy implementation and make policy plans more in line with public opinions.

\section{B. System Guarantee Mechanism}

The people's livelihood policy is related to a wide range of groups with a large number. Due to factors such as time, effort, cost, and expertise, it is difficult to make the entire public participate in policy evaluation. Therefore, public participation should be reasonably prescribed. The persons who can participate in the assessment, the public participation scope of the assessment, and the form of participation should not be decided by the decision maker based on his own view, there must be a clear and institutionalized provision. We can learn from Shanghai's practices, formulate specific work regulations, interim measures, etc., clearly define the basics, work principles, recruitment scope, evaluation awards, etc. for public participation in assessments, provide institutional guarantees for mobilizing people's participation enthusiasm and the public participation in policy assessment, and make the assessments follow a clear procedure.

\section{CONCLUSION}

The people's livelihood policy is closely related to the public interest. People are increasingly aware that as the master of the country and society, they cannot only be the objects of public policy in the course of the people's livelihood policy, passively accept the government's policy plan, they should strengthen their main body position, express their own wishes for the people's livelihood policy, participate in the formulation, execution and feedback of the people's livelihood policy, make the people's livelihood policy more represent their own interests. Therefore, the government should actively provide the public with the means to participate, receive opinions and suggestions from the masses, formulate policies based on problems, and make decisions more scientific and more rational. The government departments should think about what the masses think, meet the demands of people, continuously improve the public's sense of acquisition, and improve the credibility of the government.

\section{REFERENCES}

[1] Tang Zhijun. Public participation in the policy process: value, dilemma and trend [J]. Theory Exploration, 2009 (02): pp.124-127. 唐志君.公众 参与政策过程:价值、困境及走向 [J].理论探索,2009(02):124-127.

[2] Li Guoqi. Study on the power mechanism of public participation in the administrative decision-making [J]. Journal of the Party School of Tianjin Committee of the Communist Party of China, 2015(01):pp.7883. 李国旗.我国公众参与行政决策动力机制研究 $[\mathrm{J}]$. 中共天津市委 党校学报,2015(01):78-83.

[3] Zhu Demi, Tang Lijuan. Citizen participation in the process of public policy. Journal of the Fujian Provincial Party School of the Chinese Communist Party, 2014, (11): pp.22-26 朱德米,唐丽娟.公共政策过程 中的公民参与.中共福建省委党校学报,2014, (11):22-26

[4] Wang Sao, Xu Boya. Public Participation in the Construction of Policy Issues [J]. Theory and Modernization, 2012(06):pp.30-36. 王骚,许博雅. 论政策问题构建中的公众参与[J]. 理论与现代化,2012(06):30-36.

[5] Sun Boying. Analysis of types and applicability of citizen participation forms [J]. Journal of Renmin University of China, 2005, (5):pp. 124129. 孙柏瑛. 公民参与形式的类型及其适用性分析 [J].中国人民大 学学报, 2005, (5) : 124-129.

[6] Yang,Kaifeng and Pandey,Sanjay K.2011.Further Dissecting the Black Box of Citizen Participation:When Does Citizen Involvement Lead to Good Outcomes Public Administration Review, 71(6):pp.880-892.

[7] Wang Xixin, Zhang Yongle. The Transformation of China's Administrative Decision-Making Model--from the Managerialism Model to the Participatory Governance Model [J]. Journal of Law and Business Research, 2010(5): pp.3-12. 王锡锌、章永乐.我国行政决策 模式之转型一一从管理主义模式到参与式治理模式 $[\mathrm{J}]$.法商研 究,2010(5): 3-12.

[8] Zhu Wei. Research on the interaction model of officials, experts and the public in the process of policy formulation [D]. Nanjing University, 2012. 朱伟. 政策制定过程中官员、专家与公众的互动模式研究[D]. 南京大学,2012.

[9] Ji Yaping. Public participation in administrative decision-making process [J]. Zhejiang Journal, 2012(03):pp.164-171. 姬亚平.行政决策 程序中的公众参与研究[J].浙江学刊,2012(03):164-171.

[10] Wang Jianrong. Existing Problems in China's Public Policy Assessment and Improvements [J]. Administrative Forum, 2006(02):pp.40-43. 王建 容. 我国公共政策评估存在的问题及其改进 [J]. 行政论 坛, 2006(02):40-43.

[11] Wang Ting. Research on the Construction of Policy Issues - the Validation Based on China's Rural Social Endowment Insurance Policy [J]. Chinese Administration, 2017(06): pp.97-102. 王婷.政策问题建构 研究——基于中国农村社会养老保险政策的验证 [J]. 中国行政管 理,2017(06):97-102. 
[12] Sun Ping, Xu Yang. Realistic deviation and governance of the public orientation of China's public policy agenda setting[J]. Theory Monthly, 2012, 6 孙萍,许阳.我国公共政策议程设置公共性取向的现实偏离及 治理[J].理论月刊,2012,6

[13] Xiang Jiawu. Deviant Behaviors of Executives of Public Policy in Contemporary China: Performance, Causes and Countermeasures [J]. Journal of Sichuan Administration Institute, 2009(01):pp.11-14. 向加吾. 当代中国公共政策执行主体的偏差行为:表现、原因及对策[J].四川 行政学院学报,2009(01):11-14. 